\section{Europe falling behind}

\section{London}

A Group of prominent European industrialists has sent out a warning that European Community (EC) policy on biotechnology is falling behind that of the United States and Japan to such an extent that Europe's future position in the biotechnology industry is in jeopardy. In a paper circulated last week, the Senior Advisory Group on Biotechnology (SAGB) says that many of the biotechnology projects being paid for by the EC are "too limited in both scope and scale to have lasting impact and give a clear European profile". More ambitious projects, such as genome mapping and the design of new molecules, are recommended. And to encourage the growth of a biotechnology industry, better patent protection and more coherent product regulation are needed.

EC policy on patent protection for genetically engineered organisms is incoherent, according to Tim Roberts of ICI, particularly in the case of plants. In the United States, by contrast, a series of test cases in the 1980 s established a fairly

\section{ANTARCTIC RESEARCH}

\section{Four dead on Indian expedition \\ New Delhi}

INDIA's ninth Antarctic expedition has run into tragedy. Four members of an expedition have died and two others were incapacitated during the first week of a visit to the Weddell Sea. The Department of Ocean Development (DOD) said that the deaths were from poisoning by carbon monoxide from a diesel generator kept inside the men's sleeping quarters. An investigation has been launched.

Three of the dead were from the Geological Survey of India and the fourth was a Navy communications engineer. A request by India for assistance received a prompt response from other members of the Antarctic research community. The Soviet Union has offered to help in transporting the bodies to New Delhi, and one of the sick expedition members, suffering from a duodenal ulcer, was flown in a West German plane to the South Pole, where a US aircraft took him to Christchurch, New Zealand, for treatment.

US efforts to drop medical supplies to the other sick man, who had suffered a heart attack, failed and a Soviet aircraft will take him to New Delhi.

DOD officials said that this was the first time in eight years that a catastrophe of these proportions had struck an Indian expedition. But the depleted team is expected to continue the planned research activities.

K.S. Jayaraman

\section{CREATIONISM}

firm legal basis for plant patenting. Roberts believes a similar system is needed in Europe, so that the 'inventor' of, for example, a potato incorporating a fungicide-producing gene could obtain royalties when the same gene was subsequently bred into other varieties of potato. A European Commission directive, to be considered by the European Parliament in May, may give protection along these lines. But draft regulations from the Commission's Agriculture Directorate-General propose instead that patent protection should be removed for individual plant varieties once a plant breeder has satisfied the narrower criteria for commercial plant variety protection.

The SAGB paper also argues that proposed EC policy on product regulation may disadvantage the biotechnology industry. Nigel Poole, a member of the SAGB support group, says that existing product-safety legislation can and should be applied to the products of industrial biotechnology.

What matters are the inherent characteristics of a product and its intended use, he says, regardless of whether or not it has been produced by genetic engineering. "Without a suitable framework of legislation, we cannot justify the long-term development of products", Poole says.

Two forthcoming EC directives will lay down strict rules on the contained use and deliberate release of genetically manipulated organisms (GMOs). The rules will apply to academic research projects as well as to commercial products containing GMOs. Despite the SAGB's opposition to stricter controls for biotechnology, and sympathy for the industrialists' views from some quarters within the European Commission, the directives will probably be adopted in March and implemented through national legislation. Several member states, including the United Kindom (see Nature 343, 4; 1990) are already drawing up their own laws.

Peter Aldhous

\title{
Approval for degrees turned down
}

\section{San Francisco}

Although a final decision will not be made for several weeks, the state of California is expected to deny approval for the Institute of Creation Research Graduate School (ICRGS), located near San Diego, to issue masters' degrees in science. The recommendation comes after more than two years of investigation into ICRGS, and had been expected by both the state department of education and the school, which offers masters' degrees only and holds courses solely during the summer.

Under California law, non-accredited institutions must receive state approval to issue academic degrees by showing they offer coursework and facilities comparable to accredited institutions, according to William Ruckeyser, special assistant to the state superintendent of public instruction. ICRGS, which has ten full-time faculty members and taught about 20 students last summer, has been receiving permission to issue masters' degrees in astrogeophysics, biology, geology and science education.

Academic investigative teams visited the school in 1988 and again last summer, ultimately recommending against reapproval. Their latest findings will be brought to the state Council for Private Post-Secondary Educational Institutions, which then reports to California's superintendent of public instruction, Bill Honig, who makes the final decision. But Honig has already indicated he will follow the recommendation, said Ruckeyser.

The decision has been praised as a victory for science over creationism. "The committee made the right decision for the

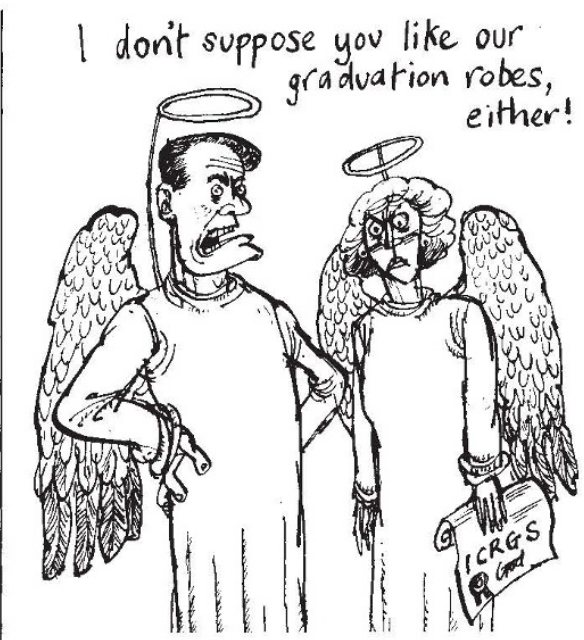

right reason", said Eugenie Scott, executive director of the Berkeley-based National Center for Science Education, who asserted that coursework at the institute was far below today's scientific standards. "The ICR was rejected because they do a terrible job of training students. Any institution in California with as poor a program as the ICR would also be rejected." Anticipating ultimate rejection, John Morris ICRGS vice-president, challenged the objectivity of the latest investigative committee and declared that "they came with an agenda to shut us down". Listing courses that include earth structure, tectonics, and sedimentary geology, Morris said, "We are a Christian school, but we teach science". He indicated that the school will seek an administrative appeal to the expected decision. 